\title{
PROFESJONALIZM, WIERNOŚĆ, BEZSTRONNOŚĆ: PODSTAWOWE WYMOGI STAWIANE TEUMACZOM ZAWODOWYM?
}

\section{Uwagi wstępne}

Wielka dyskusja, która przez ostatnie dwa lata toczyła się w Polsce, w różnych kręgach uniwersytecki, sejmowych, senackich, medialnych, a która poprzedziła uchwalenie nowej ustawy o szkolnictwie wyższym, wyraźnie wykazała, że zmienia się kompletnie wizja szkoły wyższej i sposobu kształcenia uniwersyteckiego. W tym nowym podejściu nie tylko chodzi o przekazanie studentom pewnej wiedzy, ale przede wszystkim o przygotowanie ich do konkretnych zawodów, aby zaraz po studiach odnaleźli swe miejsce w gospodarce.

Podstawowe zawody, do których przygotowują studia neofilologiczne, to zawody nauczyciela języków obcych i tłumacza. Oczywiście możemy mówić o przygotowaniu naszych studentów do innych zawodów: mediatora kulturowego, animatora kultury itd. Również o tym, że nasi studenci są przygotowani do samokształcenia i do dostosowywania swoich kwalifikacji do potrzeb rynku. Niemniej jednak, kiedy zaczynamy mówić o konkretnych zawodach, a mam tu na myśli zawód tłumacza, to musimy podnieść problem kształcenia w taki sposób, aby przyszły adept tego zawodu był wyposażony w potrzebną wiedzę, ale również umiejętności profesjonalnego dostosowania się do różnych warunków pracy, którą będzie wykonywał.

Jeżeli zatem myślimy o tym konkretnym zawodzie, jakim jest tłumacz, to od razu musimy stwierdzić, że tradycja kształcenia w tym kierunku na uniwersytecie w Polsce nie jest długa. Przed przełomem w 1990 roku na uczelniach w Polsce, poza Instytutem Lingwistyki Stosowanej w Warszawie, praktycznie nigdzie nie realizowano całościowego programu kształcenia tłumaczy. Oczywiście po 1990 roku na wielu uczelniach pojawiły się hasła kształcenia tłumaczy, ale żaden z proponowanych programów nie był do końca profesjonalny, bo w Polsce nie było specjalistów $\mathrm{z}$ tej dziedziny na co najmniej uniwersyteckim poziomie. 
Sytuacja zmieniła się, kiedy powstały programy EMCI (European Master in Conference Interpretation) i EMT (European Master in Translation). Chęć przystąpienia do tych programów spowodowała, że niektóre uniwersytety w Polsce zaproponowały programy kształcenia tłumaczy i tłumaczy konferencyjnych dostosowane do wymogów europejskich. I w tym momencie autorzy programów zdali sobie sprawę, że w gruncie rzeczy kształcimy młodych adeptów tego zawodu, proponując im przede wszystkim kształcenie językowe, rozwijające kompetencję translatoryczną i kształcenie w różnych dziedzinach wiedzy typu: tłumaczenie prawnicze, techniczne, medyczne itd., zakładające znajomość terminologii i tekstów specjalistycznych. Tymczasem okazało się, że zbyt mało czasu poświęcamy na dyskusję, w jaki sposób tę wiedzę zawodową wprowadzić do różnych szeroko pojmowanych kontekstów komunikacyjnych, z którymi tłumacz będzie spotykał się podczas wykonywania swego zawodu.

Nauczający skupiają się przede wszystkim na nauczaniu terminologii specjalistycznych, na analizowaniu różnego typu dokumentów, z którymi tłumacz może mieć do czynienia w swej pracy, na kształceniu specjalistów w dziedzinie dwóch lub ostatnio trzech języków, specjalistów z kulturoznawstwa porównawczego, ale np. mało czasu poświęcamy na dyskusję o tym, czym jest albo jak się wyraża etyka zawodowa thumacza, na analizę różnych sytuacji komunikacyjnych, z jakimi przyjdzie się zmierzyć przyszłym thumaczom w ich praktyce zawodowej.

Musimy zatem w tej właśnie chwili postarać się oddzielić w naszym kształceniu dwie sprawy: bardzo precyzyjną kompetencję językowo-kulturową i kompetencję merytoryczną w danej dziedzinie od kompetencji zawodowej, związanej z pewnymi normami zachowań, etyką, postawami, ideologiami itp. Zastanówmy się zatem, kto i co reguluje te sprawy. Przypomnijmy kilka faktów dotyczących kształcenia tłumaczy i dokumentów regulujących ich funkcjonowanie.

\section{Początki kształcenia thumaczy i reguł rządzących tym zawodem}

Jeżeli przyjrzymy się dzisiaj mapie instytucji kształcących tłumaczy, chociażby w Europie, to możemy stwierdzić, że jest ich relatywnie dużo. Nie zapominajmy jednak, że pierwszą liczącą się w świecie szkołą tłumaczy była ETI (École de Traduction et d'Interprétation) w Genewie otwarta w 1941 roku. Inne szkoły tego typu pojawiły się dopiero w latach pięćdziesiątych XX wieku, jak choćby ESIT w Paryżu, założona w 1957 roku. Trzeba również podkreślić, że to właśnie w latach pięćdziesiątych XX wieku rozpoczął się rozwój przekładoznawstwa naukowego.

W tym samym czasie, w 1953 roku, powołano do życia FIT (Międzynarodowe Stowarzyszenie Tłumaczy). Ale jednocześnie to stowarzyszenie było w stanie uchwalić Kartę thumacza FIT dopiero dziesięć lat później, tzn. w 1963 roku w Dubrowniku. Karta, zmodyfikowana w 1994 roku, określa m.in. obowiązki i prawa 
thumacza, co możemy przyjąć jako pewne zasady etyczne w wykonywaniu tego zawodu. Jeżeli natomiast chodzi o thumaczy przysięgłych, to grupująca ich organizacja EULITA (European Legal Interpreters and Translators Association) powstała 26 listopada 2009 roku, a więc dopiero dwa lata temu. W tym kontekście, jeżeli chcemy w programach kształcenia thumaczy uwzględnić wymiar etyczny tego zawodu, to pierwszym punktem odniesienia powinny być różne kodeksy etyki zawodowej thumaczy.

\section{Główne zasady kodeksów etyki zawodowej tlumaczy}

Zacznijmy od Karty thumacza FIT, która wyraźnie określa wymogi stawiane tłumaczom: kompetencje w dwóch językach, a szczególnie w tym, na który się tłumaczy (punkt 6), kompetencje w dziedzinie, która jest przedmiotem tłumaczenia (punkt 7), ale również określa niektóre reguły zachowań, zwracając uwagę na pewne wymogi zawodowe. Jednakże to wszystko przybiera formę dość ogólnikowych sformułowań, np. „(...) thumacz musi wykazywać pewną ogólną kulturę (...) i nie podejmować się thumaczenia w dziedzinie, która nie leży w jego kompetencjach" (punkt 7); „tlumacz nie powinien stosować nieuczciwej konkurencji w uprawianiu swego zawodu” (punkt 8); „tłumacz powinien uznawać uzasadnione interesy użytkownika, traktując jako tajemnicę zawodową wszelkie informacje, jakimi dysponuje przy wykonywaniu powierzonego mu thumaczenia" (punkt 10). Wiele z tych sformułowań jest z pewnością ważnych, ale zdecydowanie nie są one zbyt precyzyjne, gdyż większość z nich znajduje się w kodeksach etyki innych zawodów, np. w kodeksie etyki zawodu notariusza. Te ogólne sformułowania Karty tłumacza FIT znalazły swe odzwierciedlenie w kodeksach bardziej specyficznych, odnoszących się do różnych dziedzin funkcjonowania tłumaczy. I tak np. istnieją kodeksy thumaczy przysięgłych, tłumaczy medycznych, środowiskowych itp. Trzeba jednak stwierdzić, że mimo pozornego podobieństwa, bo przecież wszystkie te kodeksy odwołują się do międzynarodowych uregulowań, nie są one identyczne we wszystkich krajach. Pewne jest, że wśród wszystkich tych kodeksów dominują, jeżeli chodzi o liczbę, kodeksy tłumaczy przysięgłych lub kodeksy thumaczy pojawiających się w kontekstach prawnych. Często, po określeniu w sposób bardzo ogólnikowy zasad etyki zawodowej, opisują one bardziej precyzyjnie różne dokumenty i różne konteksty pracy thumacza, sugerując pewne normatywne rozwiązania translatoryczne.

W Polsce dysponujemy Kodeksem tłumacza polskiego, który, wzorując się na Karcie thumacza FIT, określa w sposób bardzo ogólnikowy prawa i obowiązki wszystkich tłumaczy, oraz Kodeks tłumacza przysięgłego, który jest bardziej precyzyjny i dzieli się na dwie części:

I. Zasady etyki zawodowej

II. Zasady praktyki zawodowej 
Ta druga część dzieli się jeszcze na:

1. Tłumaczenie pisemne

2. Tłumaczenie ustne

Już na tym etapie widzimy, że w tej ograniczonej dziedzinie thumaczenia prawniczego, zakładającej, że tłumacz ma kompetencje w języku specjalistycznym prawniczym, w terminologii, znajomości prawa, prawa porównawczego itd., może on w swoim życiu zawodowym spotkać się z różnymi kontekstami komunikacyjnymi wykonywania swego zawodu, co powoduje, że właściwie musimy mówić o różnych zawodach lub chociażby o różnych aspektach tego samego zawodu. W różnych krajach, w tym również w Polsce, tłumacz przysięgły z jednej strony ma do czynienia $\mathrm{z}$ tłumaczeniem tekstów prawnych i prawniczych, a $\mathrm{z}$ drugiej często musi być thumaczem środowiskowym i pracować na potrzeby policji, notariatu, sądu czy administracji państwowej.

We wszystkich programach kształcenia tłumaczy wyraźnie oddziela się kształcenie thumaczy i thumaczy konferencyjnych, ale z thumaczem środowiskowym, a więc thumaczącym ustnie w sposób konsekutywny lub za pomocą szeptanki, sprawa ta nie jest taka ewidentna. Można by zatem paradoksalnie stwierdzić, że kształcąc thumaczy na uniwersytecie, nie do końca wiemy, w jakim dokładnie kontekście przyjdzie im wykonywać ten zawód.

Podział klasyczny obejmuje:

- thumacza/thumacza konferencyjnego,

- thumacza literackiego/nieliterackiego,

- thumacza tekstów pragmatycznych,

ale już tu rodzi się pytanie: w jakich dziedzinach? Czy tłumacze powinni być przygotowani do wszystkiego, co życie przyniesie? A jeżeli tak, to jak ich do tych różnych kontekstów przygotować? Jednak nie budzi wątpliwości, że na poziomie uniwersyteckim nie jesteśmy $\mathrm{w}$ stanie stwierdzić, czy ktoś stanie się thumaczem przysięgłym czy nie. Zresztą status tłumacza przysięgłego, wymogi mu stawiane, procedury powoływania, pewne ograniczenia nie są identyczne w krajach np. Unii Europejskiej, a często bardzo się różnią (Cf. Wowro, Kubacki 2011). Jeżeli zatem zamierzamy w kształceniu thumaczy wprowadzać do programów zagadnienia związane z etyką wykonywania tego zawodu, to właściwie jedynym punktem odniesienia są kodeksy tłumaczy. Zastanówmy się jednak, jak te kodeksy są postrzegane przez osoby wykonujące ten zawód.

\section{Funkcje kodeksów zawodowych tlumaczy}

W ciągu ostatnich kilku lat w świecie specjalistów w dziedzinie kształcenia tłumaczy toczy się dyskusja na temat przydatności czy użyteczności tych kodeksów. Wielu badaczy ankietowało profesjonalistów, aby dowiedzieć się, czym dla nich są 
te kodeksy, jaką spełniają funkcję w wykonywaniu zawodu. Biernacka (2010: 91) stwierdza na przykład, że w krajach, w których nie ma obowiązku kształcenia tłumaczy, kodeks etyki thumacza jest jedynym dokumentem, który opisuje zasady funkcjonowania tego zawodu.

Jeżeli jednak spojrzymy na rezultaty różnych ankiet przeprowadzanych wśród praktykujących thumaczy, np. Tryuk (2004), Hale (2007) czy Biernacka (2010), to wynika z nich jasno, że większość praktykujących tłumaczy stwierdza, że kierują się swym własnym kodeksem opartym na dekalogu i zdrowym rozsądku. Ogólnie odpowiedzi na pytanie, czym jest dla ankietowanego kodeks zawodowy thumacza, można podzielić na trzy grupy odpowiedzi: dla niektórych jest pewną biblią, inni kierują się w swej pracy zdrowym rozsądkiem, a jeszcze pewna grupa deklaruje, że te kodeksy niczemu nie służą. Ostatecznie Hale (2007) stwierdza, że mimo iż kodeksy te określają najwyższe standardy, do których thumacze powinni dążyć, nie precyzują, w jaki sposób tłumacze powinni rozumieć swoją rolę społeczną i sam proces tłumaczenia czy jak powinni stawiać czoło pojawiającym się trudnościom. Podsumowując, Biernacka (2010: 94) stwierdza: „wszelkie kodeksy etyki zawodowej thumaczy mają być z jednej strony swego rodzaju drogowskazem postępowania, z drugiej zaś nie są one na tyle szczegółowe, aby udzielić odpowiedzi na wszystkie pytania i rozwiać wszelkie wątpliwości nurtujące thumaczy”. Według Hale (2007), która porównała szesnaście kodeksów etycznych obowiązujących w dziewięciu krajach, zasady postępowania tłumaczy można podzielić na trzy grupy. Wymaga się od thumacza:

- profesjonalizmu,

- wierności i precyzji,

- bezstronności (neutralności).

Przyjrzyjmy się zatem tym pojęciom.

\subsection{Profesjonalizm}

Chociaż to pojęcie jako takie nie pojawia się w omawianych kodeksach, obejmuje ono wszelkie kwestie związane z zachowaniem przez tłumacza właściwej postawy moralnej i zawodowej. Jest ono niezwykle pojemne i oznacza:

- zachowanie tajemnicy zawodowej, którą objęte są wszelkie informacje uzyskane w związku z tłumaczeniem;

- solidarność zawodową i radzenie sobie z konfliktami;

- osobistą niezawodność, dyspozycyjność oraz doskonalenie kompetencji językowych i specjalistycznych (za: Biernacka 2010: 99).

Właściwie tylko jedna z tych reguł odnosi się stricte do zawodu tłumacza: doskonalenie kompetencji językowych i specjalistycznych, gdyż dwie pozostałe dotyczą wielu innych zawodów. Jeżeli chodzi zatem o tę specyficzną dla zawodu thuma- 
cza regułę, to jest ona precyzowana zarówno w Karcie thumacza polskiego, jak i w Kodeksie thumacza przysięgłego i sprowadza się do stwierdzenia, że thumacz jest zobowiązany do stałego doskonalenia swoich kwalifikacji translatorskich, językowych i merytorycznych. A więc wszyscy thumacze mają obowiązek ustawicznego kształcenia, np. w formie studiów podyplomowych, warsztatów translatorycznych lub zgłębiania wiedzy i poszerzania swych umiejętności na zasadzie samokształcenia.

To, co mnie niepokoi w tym kontekście, to fakt, że w procesie samokształceniowym zwraca się uwagę na poszerzanie terminologii, zdobywanie wiedzy w różnych dziedzinach, a zupełnie zapomina się o zwykłym poszerzaniu wiedzy językowej na poziomie składni czy stylistyki. Jest truizmem stwierdzenie, że każdy język żyje i podlega ciągłym zmianom. U tłumacza zakłada się, że zna on perfekcyjnie dwa lub trzy języki. Niemniej jednak te języki ciągle się zmieniają, niekoniecznie w dziedzinach specjalistycznych. Wszelkie warsztaty thumaczeniowe nie przewidują zwykłego doskonalenia językowego, a tylko doskonalenie terminologiczne, translatoryczne. Myślę, że tu jest pewna luka. Może właśnie w tym momencie powinno się uznać, że glosariusze lub nowoczesne gramatyki, jak np. ta autorstwa Darskiego (2010), powinny być również punktem odniesienia dla thumaczy, bez zakładania, że oni już „wszystko wiedzą" na poziomie stricte językowym. Jakkolwiek patrzeć na to, co zostało powiedziane, jedno jest pewne: rozumienie pojęcia profesjonalizm może być tylko bardzo przybliżone, ale zdecydowanie nie jest ostre.

\subsection{Wierność i precyzja}

Ta zasada wydaje się fundamentalna dla każdego thumaczenia i pojawia się we wszystkich kodeksach etyki zawodowej tłumaczy. Jeżeli jednak bliżej przyjrzymy się tej regule, to dowiemy się, że thumaczenie wierne nie oznacza thumaczenia dosłownego, ale jednocześnie nie można pozwolić sobie na tłumaczenie wolne. Wynika z tego, że thumacz sam musi określić, co rozumie przez pojęcie thumaczenia dosłownego i wolnego. Tłumacze wykonują więc kompletne i precyzyjne tłumaczenie, nie zmieniając, ujmując lub dodając, w stosunku do tego, co zostało powiedziane lub napisane, oraz nie komentując. Jest absolutnie jasne, że wszystkie te sformułowania pozostawiają duży margines możliwych interpretacji.

\subsection{Bezstronność, neutralność}

Jeszcze raz mamy do czynienia z zasadą, która nie jest regułą lingwistyczną, kognitywną, specyficzną tylko i wyłącznie dla zawodu thumacza. To zasada związana z zachowaniami dotyczącymi wielu innych zawodów, np. notariusza, zawodów, 
które metaforycznie moglibyśmy określić jako zawody typu „służący dwóch panów” (Cf. Kaufmann 2006: 187). Te zawody zakładają, że ich wykonawcy muszą bezstronnie służyć dwóm stronom spotkania, nie angażując się po żadnej z nich. Znowu wraca więc wizja tłumacza jako ,przezroczystej szyby”? I właśnie Kaufmann (2006: 196) tak to określa: „Nadszedł moment, aby od nowa przemyśleć i ponownie zdefiniować status thumacza ustnego, tak aby zaczął być postrzegany nie jako wierny sługa partnerów w dyskusji od początku do końca, ale jako myślący urzędnik, ekspert w dziedzinie języka i komunikacji”"1.

$\mathrm{Z}$ tego wszystkiego, co zostało powiedziane, wynika, że kodeksy etyki zawodowej thumacza przedstawiają ogólne dyrektywy, bardziej moralne niż stricte zawodowe, które poprzez hasła profesjonalizmu, wierności i bezstronności naprowadzają tłumacza na to, w jaki sposób ma postępować w kontekstach zawodowych, ale w żadnym wypadku nie rozstrzygają kwestii zachowań czy sposobu postępowania w sytuacjach bardziej specyficznych, które na co dzień pojawiają się podczas wykonywania zawodu. Do takich sytuacji należą np. interakcje konfliktowe. Osobiście zorganizowałam w 2004 roku ankietę wśród tłumaczy polskich dotyczącą ich zachowań w sytuacjach konfliktowych pojawiających się podczas tłumaczenia. Celem tej ankiety było zmierzenie skali tego problemu, opisanie rodzajów konfliktów pojawiających się w codziennej pracy i sklasyfikowanie postaw thumaczy wobec zaistniałych sytuacji (Cf. Tomaszkiewicz 2006). Omawiane konflikty dotyczyły zarówno uczestników konwersacji, sporów między thumaczem a klientem, jak i różnicy zdań między thumaczami, kiedy każda ze stron dysponowała własnym mediatorem językowym. Ale może nie to jest $\mathrm{w}$ tej chwili najważniejsze. Istotny jest fakt, że tylko $10 \%$ ankietowanych odpowiedziało negatywnie na pytanie, czy starali się w jakiś sposób zaradzić tym konfliktom. Czyli mimo wizji tłumacza jako przezroczystej szyby, wyłaniającej się z kodeksów etyki zawodowej, większość kieruje się tym, co nazywa zdrowym rozsądkiem i stara się intuicyjnie realizować zasadę Grice'a (1979) potrzeby społecznych interakcji kooperacyjnych.

$\mathrm{Z}$ ankiety zatem wynika, że thumacze czują się odpowiedzialni za kooperacyjny przebieg spotkania i starają się rozwinąć różne strategie grzeczności językowej, aby złagodzić powstały konflikt ${ }^{2}$. Problem polega na tym, że 60\% ankietowanych stwierdziło, że ich dążenia do rozwiązania sytuacji konfliktowych nie spotkały się z aprobatą klientów. Wyrażali oni niezadowolenie właśnie ze zbyt „,ugrzecznionego” tłumaczenia, które nie umożliwiało im przekazania drugiej stronie swych pretensji i sformułowania w odpowiedni sposób zarzutów. Ankieta wykazała niezbicie, że tłumacze, nie do końca kierując się zasadami wyrażonymi w kodeksach, a bardziej,

\footnotetext{
${ }^{1}$ Tłumaczenie T. Tomaszkiewicz.

${ }^{2} \mathrm{Na}$ temat sposobów łagodzenia sytuacji konfliktowych przez tłumaczy można przeczytać w moim artykule (Tomaszkiewicz 2006) i w tekście o grzeczności językowej (Tomaszkiewicz 2005). Omawiam również to zagadnienie w kontekście autocenzury (Tomaszkiewicz 2011).
} 
jak to nazywają, zdrowym rozsądkiem, stają się często stroną interakcji konwersacyjnej (mam tu na myśli tłumaczy środowiskowych), sami ją organizując i dbając o jej właściwy, w ich mniemaniu, przebieg.

\section{Nowe sposoby pojmowania etyki zawodowej tlumaczy}

Ostatnimi czasy wielu specjalistów związanych z kształceniem tłumaczy zaczyna widzieć w nowym świetle to, co nazywamy etyką thumaczy (Cf. Angelelli 2006; Baker 2010; Kahane 2007). Baker (2010) stwierdza:

Translator and interpreter education has traditionally sidestepped the issue of ethics. At most, students are made aware of existing professional codes of ethics, which generally focus on the relationship between the translator and the client and stress the need of impartiality and fidelity. But translators and would be translators need to adopt a more reflexive and critical stance towards the tasks in which they engage; they have the responsibility towards participants other than the client who pays their fees, and indeed towards society at large.

Zdaniem Baker, pojęcia bezstronności i wierności powinny być traktowane z różnych punktów widzenia. Badaczka precyzuje (Baker: 2011), że każdy tłumacz ma swoje własne opinie, wierzenia, własną etykę czy religię, które to wartości mogą przeszkodzić mu w podjęciu się tłumaczenia tekstów pozostających w konflikcie z jego systemem wartości. Z tego powodu proponuje, aby nie mówić o jakiejś ogólnej etyce zawodowej, a etyce dotyczącej każdej wybranej sytuacji. Takie myślenie pojawia się również w pracach Angelelli (2006) dotyczących tłumaczenia medycznego. Nie należy również zapominać o sytuacjach wojny czy konfliktów między różnymi grupami społecznymi, gdzie rola thumacza jest bardzo ważna, ale cały czas ryzykuje on nawet życie (Cf. Kahane, 2007). Mogłabym tu przytoczyć jeszcze wielu autorów, którzy stwierdzają, że zachowanie etyczne thumacza sprowadza się do ciągłego balansowania między swymi własnymi prawami a prawami innych, które musi chronić.

\section{Wnioski końcowe}

Bardzo trudno jest mówić w tym miejscu o klarownych wnioskach wynikających z tego, co zostało wcześniej przedstawione. Powinni się wszyscy zgodzić, że w kształceniu zawodowym tłumaczy musi znaleźć się miejsce na omawianie etyki tego zawodu. Wiemy również, że punktem odniesienia w tej materii są istniejące już kodeksy zawodowe thumaczy. Niemniej jednak wykazaliśmy, że kodeksy te niezbyt precyzyjnie określają zasady etyczne, gdyż nie uwzględniają pewnych specyficz- 
nych sytuacji, w których może znaleźć się thumacz i z którymi musi sobie radzić. Teoretycznie mówi się o tym, że thumacz powinien umieć wyważyć racje między tym, co dotyczy jego własnej etyki, a tym, co jest społecznie oczekiwane. Podczas kształcenia musimy zatem nauczyć przyszłych adeptów tego zawodu właściwego analizowania różnych sytuacji komunikacji społecznych, które mogą pojawić się podczas ich pracy. Ale w ocenie tego, co tłumacz może, musi czy czego nie powinien robić, jestem bardzo sceptycznie nastawiona do haseł głoszonych np. przez Baker, że każdy tłumacz może zadecydować sam, czy chce lub nie tłumaczyć dany tekst ze względu na głoszone w nim poglądy. Gdybyśmy się podpisali pod taką wizją roli tłumacza w społeczeństwie, to jednocześnie musielibyśmy zaakceptować fakt, że np. jakiś lekarz nie chce kogoś leczyć, bo ma on inne przekonania religijne czy moralne albo to, że jakiś nauczyciel decyduje sam, że kogoś chce uczyć, a kogoś nie. $\mathrm{Z}$ całą mocą chcę $\mathrm{w}$ tej konkluzji podkreślić fakt, że zawód tłumacza jest m.in. pewną misją społeczną i z tego punktu widzenia ta misja powinna być wolna od wszelkiej ideologii. Myślę, że to ostatnie stwierdzenie powinno wpisywać się w to, co chcemy uznać za etykę zawodową thumacza.

\section{Literatura}

Angelelli, C.V., (2006): „Validating professional standards and codes: Challenges and opportunities”. Interpreting 8:2, Amsterdam: John Benjamins Publishing Company, S. 175-193.

Baker, M. (2010): Abstracts $5^{\text {th }}$ International Maastricht, Łódź Duo Colloquium on Translation and Meaning, S. 9.

Baker, M., Maier, C. (2011): „Ethics in Interpreter \& Translator Training: Critical Perspectives”, The Interpreter and Translator Trainer 5 (1). Manchester: St Jerome Publishing, S. 1-14.

Biernacka, A. (2010): Funkcje tlumacza w rozprawie sądowej. Doktorat w dziedzinie językoznawstwa stosowanego, obroniony na Uniwersytecie Warszawskim (promotor Małgorzata Tryuk).

Chartre de Traducteur, <http://www.fit-ift.org/fr/charte.php> (dostęp 29.04. 2012).

Darski, J. (2010): Deutsche Grammatik. Ein völlig neuer Ansatz. Frankfurt a.M.-Berlin-Bern-BruxellsNew York-Oxford-Wien: Peter Lang.

Grice, H. P. (1979): „Logique et conversation”, Communications 30, S. 57-72.

Hale, S. (2007): Community Interpreting. Houndmills, Basingstoke, Hampshire: Palgrave Macmillan.

Kahane, E. 2007, « Les interprètes dans les conflits: les limites de la neutralité »<http://www.aiic. net/ViewPage.cfm?article_id=1981\&plg=2\&slg=2> (konsultowana 25.04.2011).

Karta tłumacza polskiego: $<$ http://www.stp.org.pl/index.php?id_page=203>.

Kaufmann, F. (2006): «L'interprète serviteur de plusieurs mîtres ? ». In M. Wolf (Hrsg.): Übersetzen Translating - Traduire: Towards a «Social Turn»? Wien-Berlin: LIT Verlag, S. 187-198.

Kodekst tłumacza przysięgłego, <http://www.tepis.org.pl/towarzystwo/kodeks.pdf $>$.

Tomaszkiewicz, T. (2005): „Grzeczność francuska na tle koncepcji grzeczności językowej”. In: M. Marcjanik, Grzeczność nasza i obca. Warszawa: Wydawnictwo Trio, S. 11-24.

Tomaszkiewicz, T. (2006): «Le comportement de l'interprète communautaire dans des interactions conflictuelles ». In M. Wolf (Hrsg.): Übersetzen - Translating - Traduire: Towards a «Social Turn»? Wien-Berlin: LIT Verlag, S. 275-284. 
Tomaszkiewicz, T. (2011): «Le traducteur entre la censure politique imposée et l'autocensure pratiquée ». In: M. Ballard, Censure et traduction. Arras: Artois Presses Université.

Tryuk, M. (2004): L'Interprétation communautaire. Des normes et des rôles dans l'interprétation. Warszawa: Wydawnictwo Tepis.

Wowro, I., Kubacki, A.D. (2011): Europejskie modele ustanawiania thumaczy przysięgłych oraz kryteria dopuszczające do wykonywania zawodu w wybranych krajach Unii Europejskiej, <http://www.stp. org.pl/> (konsultowany: 14.05.2011). 